\title{
Chinese Cross-Border Electricity Supplier Logistics Development Analysis
}

\author{
Wei Wang \\ Beijing Wuzi University, Beijing, China \\ Email: wangwei199304@126.com
}

Received 30 June 2016; accepted 25 July 2016; published 28 July 2016

Copyright (C) 2016 by author and Scientific Research Publishing Inc.

This work is licensed under the Creative Commons Attribution International License (CC BY). http://creativecommons.org/licenses/by/4.0/

(c) (i) Open Access

\begin{abstract}
Cross-border electricity supplier logistics countries need to focus on the factors. China's crossborder electricity supplier is a part of Chinese enterprises valued. In order to effectively understand the development of China's cross-border electricity supplier logistics, this paper uses SWOT analysis. The development of China's cross-border electricity supplier logistics presents advantages, opportunities and challenges. In this paper, the method is to use time-series forecasting model, which is China's import and export trade size from 2000 to 2014, to carry out an accurate forecast. This paper presents that the development of China's cross-border electricity is vital and China has the material resources of development of cross-border electricity supplier logistics. Cross-border electricity supplier needs the support of Chinese enterprises and government assistance. Development of cross-border electricity supplier logistics, which makes Chinese products can be sold in various countries, will give China a greater profit and enhance China's reputation.
\end{abstract}

\section{Keywords}

Cross-Border Electricity Supplier Logistics, SWOT Analysis

\section{Introduction}

Cross-border electricity supplier has become the most important channel for people to consume, which means that it takes the realm of the country, and the concept and meaning of the original meaning are very different. In 2000, people generally take consumption patterns mainly to experience the store and purchase in two main ways. According to incomplete statistics, consumers to experience the store account for more than $85 \%$, it is well described in the previous cross-border electricity supplier appeared: people often choose to personally go to the store to buy products, the main reason may be that consumers want to buy goods and reliable quality of goods can be guaranteed; select purchasing group is mainly because they are in good condition, good condition con- 
sumers will pursue high-quality goods, so consumers will choose foreign products, but will beconstrained by practical conditions. Consumers are often only through the purchasing behavior of other channels to make purchase. As in recent years, the emergence of cross-border electricity supplier gives each country in the world a big space for development, cross-border electricity supplier can not only increase the consumption of a country, but also brings substantial profits to countries and the true realization of global integration. Many scholars had studied the cross-border electricity supplier: Wangbi Hong scholar (2014) proposed that the development of cross-border electricity supplier was the inevitable result of an era of big data [1]. Wang Mingyu and Liao Zhen (2014) point out that for the development of China's cross-border electricity supplier, there are still many problems that we should pay attention to [2]. Xi Bo (2015) believes that cross-border electricity business in this way is an opportunity for the development of China's business, but there are still many difficulties and challenges in the process of the development of Chinese enterprises [3]. Xu Song and Zhang Yanyan (2015) think that the cross-border electricity supplier development is an important way for China to export Chinese products [4]. Xu Fu (2015) and Meng Shuai (2016) propose that the development of cross-border electricity supplier logistics needs to establish overseas positions, and they think that this approach can reduce logistics costs [5] [6]. Many scholars are using theoretical knowledge to express their point of view, I use the SWOT analysis and I have studied and analyzed the development of Chinese cross-border electricity supplier logistics, at the same time, the paper also uses a time-series forecasting model, it will be a reasonable forecast for China's deal size in the future, and the results are very reliable. SWOT analysis method is suitable to solve things: it can analyze many aspects of things; it is a good tool for cross-border electricity supplier logistics; and it can clearly analyze the current situation of China. SWOT analysis of China's cross-border electricity supplier logistics' strengths and weaknesses is the highlight of this article.

\section{Chinese Cross-Border Electricity Supplier Logistics Analysis}

In recent years, China's cross-border electricity supplier has been great development, China's cross-border electricity supplier is a strong guarantee for China's development, in order to clearly analyze the status quo of crossborder electricity supplier in China, we often use is SWOT analysis of the way analysis, SWOT analysis of the main features is the advantage of a comprehensive analysis of the situation, weaknesses, opportunities and threats, providing a good target to guide the development of a situation. China's cross-border shops to SWOT analysis are shown in Table 1.

From the SWOT analysis we can see that China's strengths are mainly three points, first, why the crossborder electricity supplier can develop rapidly in China, the main reason is because of the rapid development of China's economy, according to CCTV reported that China' economy is now ranked second in the world, second only to the United States the political core, China's reform and opening up and the people's democratic dictatorship has led the Chinese economy toward a well-off society, the development of China's economy is bound to make consumers more money to buy high-quality products, thus contributing to the development of cross-border electricity supplier. Second, in recent years, cross-border electronic business scale is gradually increased, for China, in Ningbo, Shanghai, Zhengzhou, Hangzhou and Chongqing five cities are gradually establish a national-level cross-border electricity supplier network operating point, which for local residents, in order to buy goods in other countries, it is not a difficult thing to do, directly from the city's cross-border electricity supplier operating point can Amoy to high-quality products. Third, China's light industry is the country's well-known enterprises, consumers in many other countries appreciate China's light industry, with the emergence of cross-border electricity supplier, which is open all consumers buy Chinese goods consumer channels to promote

Table 1. China’s cross-border shops to SWOT analysis.

\begin{tabular}{|c|c|}
\hline Advantage: & Disadvantages: \\
\hline 1. The rapid development of Chinese economy & 1. The lack of cross-border business enterprise \\
\hline 2. Increase the scale of cross-border electricity supplier & 2. Logistics problems more \\
\hline 3. "Amoy" on the forces of expansion & 3. Low investment overseas warehouse \\
\hline $\begin{array}{l}\text { Threat: } \\
\text { 1. China's product quality is poor } \\
\text { 2. Cross-border electricity supplier Product Category single } \\
\text { 3. Network Platform imperfect }\end{array}$ & $\begin{array}{l}\text { Opportunity: } \\
\text { 1. Model development B2B } \\
\text { 2. Advanced logistics and transport } \\
\text { 3. Cross-border electricity supplier more than the number of } \\
\text { exporting countries }\end{array}$ \\
\hline
\end{tabular}


the "Amoy proportion of China” forces, for other countries, China can buy cheap, good quality light industrial products, for China, increased the proportion of exports, which makes China's economy has greatly improved, to improve China's World economic status.

China also has many disadvantages that still restricting the development of China. First, China's development is ranked second in the world, but the overall strength of strong, weak feature is also part of the strength we cannot deny the fact that China's comprehensive strength and the various the development of enterprises and the overall presentation of the relationship between parts, part of the overall development constraints play a role in China's cross-border business a serious shortage of electricity, mainly because of Chinese government support is not enough, there is no business reason for confidence. Secondly, the commodity during transport, appears in the logistics problem is a lot due to the policy and the basic situation between countries are not the same, it is difficult to transport logistics costs under control, if the item cannot be smoothly through customs check was returned merchandise tends to increase the cost of logistics, companies will lose most of the benefits. Finally, in order to reduce cross-border transport of goods, the establishment of overseas warehouse is a good solution to the problem, but the funds to invest overseas warehouse construction is obviously insufficient, by attracting foreign investment approach cannot solve this problem.

Threatening China's development of cross-border electricity mainly in three aspects, China's product quality has been the domestic and foreign people suspected problem, in recent years, Chinese products are always quality problems, to the consumer to purchase a great deal of confusion, poor quality products so as to China's development of cross-border electricity form a threat, and secondly, China's cross-border electricity consumption is relatively simple product, the product has the characteristics of small items, reducing the interest of consumers. With the development of Internet of Things technology, electrical network internet also threaten China's crossborder electricity supplier development, networking platforms, buy platform, trading platform and the feedback network platform is a threat factor for China's development.

Cross-border electricity supplier modes include B2B, B2C, O2O, and B2B model of development has become China's leading cross-border electricity supplier model has become clear chance transnational Chinese consumption, China's logistics and transport more, railways, waterways, roads and Air transport has matured, has laid a solid foundation for the transport of goods, the Chinese government's strong support, has reached a savings product transportation time, reduce the cost of product transportation goals. It is understood the information in a report on eBay Group held shows that China's cross-border electricity supplier countries export more than 60, China has become the world's largest exporter, and cross-border electricity supplier to China's development provides a very good chance.

\section{Analysis of Cross-Border Electricity Supplier Logistics Deal}

For a good development analysis of China's cross-border electricity supplier, we first collected China's total import in 2000 and export trade in 2014, according to the literature, "2012-2013 cross-border electricity supplier in China market research report”, 2015 and 2016 data are forecast values, the collection the Chinese e-commerce market size from 2008 to 2014, in order to provide a strong basis for the study of the development trend of China's import and export, the course of the study, take time series analysis, time series method is suitable for different years of economic growth projections, cross-border electricity supplier and the size of China's import and export transactions and Chinese e-commerce market size data are shown in Table 2 and Table 3.

According to the model regulations, no value replaced by 0 , we use time series forecasting method, we must first graphical time series of paintings, from Figure 1, we can see that the scale of China's import and export transactions over time, showing a growing trend, which has obvious time trends change, so use time series prediction method is very suitable, however, due to the limitations of a predictive model, can only effectively predict a year of data, in order to eliminate the influence of variation in the forecasting process, this paper, we use two time series prediction, forecast China's import and export trade size in 2015 and 2016, predicted results having informative.

In general, we have taken over periods of between 3 and 20, $n$ is the smaller value, you cannot eliminate the impact of accidental deviation, $n$ value results will be inaccurate, and therefore this article taken $n=3$, prediction model equation is as follows:

A moving average $=($ A2000 + A2001 + A2002 $) / 3$, and so on;

Second moving average $=($ B2002 + B2003 + B2004 $) / 3$. 
Table 2. China’s cross-border electricity supplier and export trade size (unit: one trillion yuan).

\begin{tabular}{cccc}
\hline year & Import and export trade size & A moving average & Second moving average \\
2000 & 3.9 & 0 & 0 \\
2001 & 4.2 & 0 & 0 \\
2002 & 5.1 & 4.40 & 0 \\
2003 & 7.0 & 5.43 & 5.69 \\
2004 & 9.6 & 7.23 & 7.37 \\
2005 & 11.7 & 9.43 & 9.49 \\
2006 & 14.1 & 11.80 & 11.80 \\
2007 & 16.7 & 14.17 & 14.08 \\
2008 & 18.0 & 16.27 & 15.68 \\
2009 & 15.1 & 16.60 & 16.88 \\
2010 & 20.2 & 17.77 & 18.00 \\
2011 & 23.6 & 19.63 & 20.04 \\
2012 & 24.4 & 22.73 & 22.32 \\
2013 & 25.8 & 24.60 & 24.29 \\
2014 & 26.4 & 25.53 & 28.01 \\
2015 & 0 & 0 & 0 \\
2016 & 0 & & 29.25
\end{tabular}

Table 3. Chinese e-commerce market size (unit: one trillion yuan).

\begin{tabular}{ccccc}
\hline year & China deal size & US deal size & $\begin{array}{c}\text { Global transaction } \\
\text { size }\end{array}$ & $\begin{array}{c}\text { China accounted for the proportion of } \\
\text { global transactions }\end{array}$ \\
\hline 2008 & 2.9 & 0.6 & 6.4 & $45.31 \%$ \\
2009 & 3.6 & 0.6 & 5.9 & $61.02 \%$ \\
2010 & 4.8 & 0.6 & 7.9 & $60.76 \%$ \\
2011 & 6.4 & 0.7 & 10.6 & $60.38 \%$ \\
2012 & 8.1 & 0.8 & 13.8 & $58.70 \%$ \\
2013 & 10.2 & 1 & 17.4 & $58.62 \%$ \\
2014 & 12.6 & 1.2 & 21.6 & $58.33 \%$ \\
2015 & 15.3 & 1.5 & 26.4 & $57.95 \%$ \\
\hline
\end{tabular}

The results data are displayed in Table 1.

Prediction model: constant: $\mathrm{WN}=2 \mathrm{AN}[1]-\mathrm{BN}[2]=2 \times 25.53-24.29=26.77$,

Variable: $\mathrm{TN}=2(\mathrm{AN}[1]-\mathrm{BN}[2]) /(\mathrm{n}-1)=1.24$,

Regression: $\mathrm{YN}+\mathrm{L}=\mathrm{WN}+\mathrm{TNL}=26.77+1.24 \mathrm{~L}$,

2015 data $26.77+1.24 \mathrm{~L}=26.77+1.24=28.01$,

2016 data $26.77+1.24 \mathrm{~L}=26.77+1.24 \times 2=29.25$.

Thus, we conclude that, to increase the size of China's cross-border trading of electricity supplier year after year, deal size in 2015 reached 28.01 trillion yuan at the end of 2016, the data will reach 29.25 trillion yuan, these data indicate Chinese cross-border electricity supplier promising development, space and profit space development. The same calculation method, data in Table 3 for the Chinese e-commerce market size from 2008 to 2014. 


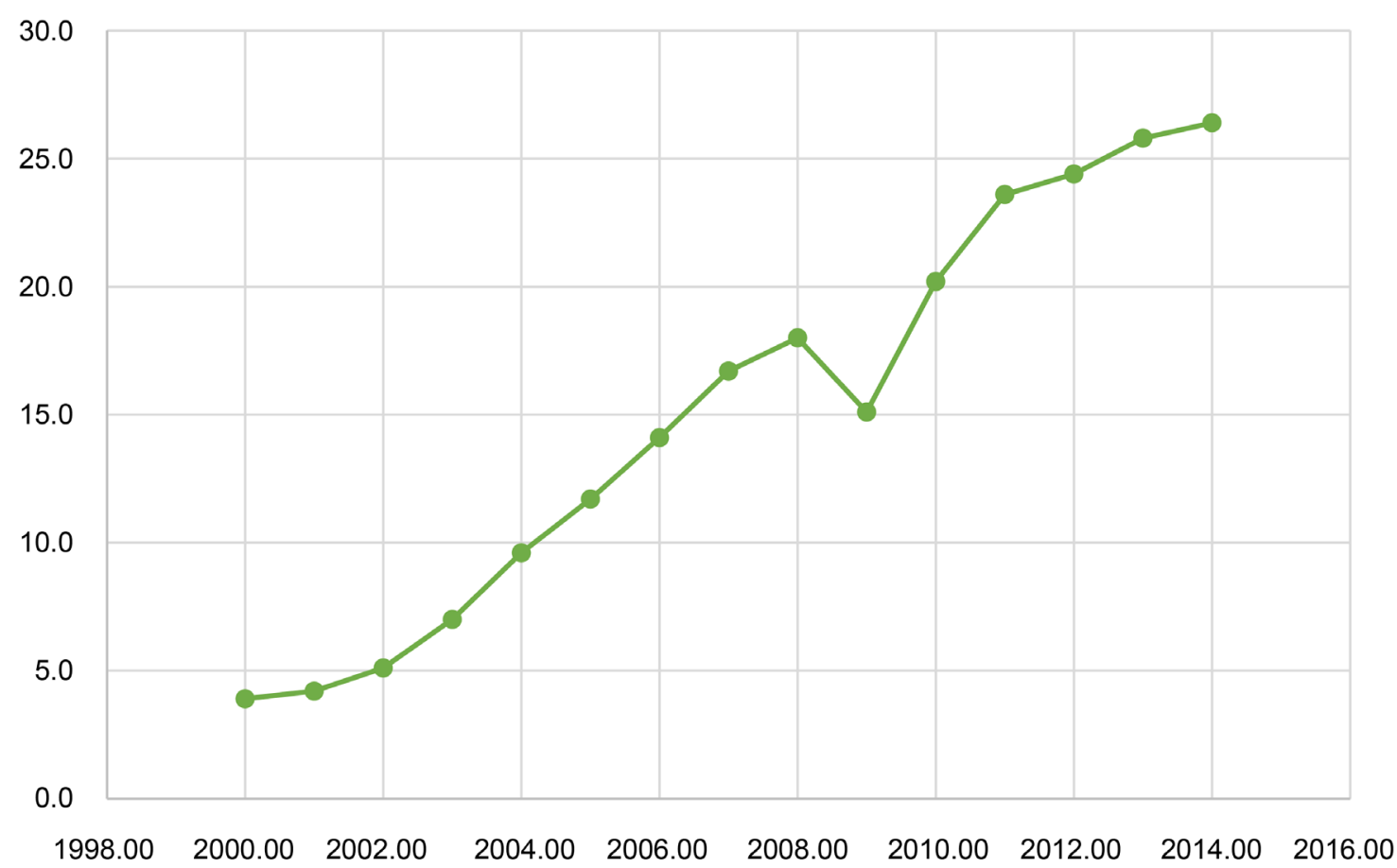

Figure 1. Time diagram of China’s import-export transaction size.

We can see from Table 3, the world's largest countries are the United States and China, the Chinese e-commerce market size is much larger than the size of the United States of transactions, transaction size increased year by year in China, the proportion of Chinese traders in the world beginning in 2009, has been half of the world, it shows the development of the whole world needs China's efforts and progress, China is an important country in the world to support e-commerce business, so that China should seize this opportunity to make full use of their own competitive advantage, strengthen the development of China's cross-border electricity supplier, the good transport Chinese goods sold to other countries, China to build brand awareness.

\section{Conclusion}

From the case of Chinese cross-border electricity business development, SWOT analysis explains the basic status of Chinese cross-border electricity supplier development. China should clear their own strengths and opportunities in today's rapid economic development, make full use of "Amoy Chinese" dominant position, improve their product quality, optimize the distribution of goods and sale models of merchandise, and improve the network trading platform of cross-border electricity supplier. It should not only make better for consumer channels, but also build a feedback of monitoring mechanism, and we must safeguard the common interests of buyers and sellers. It is the premise of Chinese cross-border electricity supplier to better develop. In the field of logistics, Chinese and foreign enterprises should strengthen cooperation, China and other countries should establish a good cross-border agreement, customs fees should be reduced between countries. B2B model is to ensure the development of Chinese cross-border electricity supplier. Chinese government and foreign government should work together to ensure the credit transactions between enterprises. It should be maintained between businesses and consumers and it is our duty and obligation to make more efforts. Future studies of cross-border electricity supplier development are an important task of contemporary scholars, however, the issue of data collection, logistics and transport uncertainties and other factors hamper the study of cross-border electricity supplier logistics.

\section{References}

[1] Hong, W.B. (2014) Study on Influential Factors Big Data Era of Cross-Border Electricity Supplier Development. Jiamusi Vocational College, No. 12, 188-189. 
[2] Wang, M.Y. and Liao, Z. (2014) Main Problems and Countermeasures for the Cross-Border Electricity Supplier. Chinese Trade, No. 33, 76-80.

[3] Xi, B. (2015) SMEs Seats Wave of Cross-Border Electricity Supplier Business Opportunities and Countermeasures. E-Commerce, No. 3, 27-28.

[4] Xu, S. and Zhang, Y.Y. (2015) Cross-Border Electricity Supplier into a "Made in China” Export New Channel. Economic Review, No. 2, 26-30.

[5] Meng, S. (2015) China Cross-Border Electricity Supplier Logistics Difficulties and Countermeasures. Chinese and Foreign Entrepreneurs, No. 5, 43.

[6] Xu, F. (2016) Chinese Cross-Border Electricity Supplier Logistics Difficulties and Countermeasures. Technology and Enterprise, No. 17, 1.

\section{Submit or recommend next manuscript to SCIRP and we will provide best service for you:}

Accepting pre-submission inquiries through Email, Facebook, LinkedIn, Twitter, etc.

A wide selection of journals (inclusive of 9 subjects, more than 200 journals)

Providing 24-hour high-quality service

User-friendly online submission system

Fair and swift peer-review system

Efficient typesetting and proofreading procedure

Display of the result of downloads and visits, as well as the number of cited articles

Maximum dissemination of your research work

Submit your manuscript at: http://papersubmission.scirp.org/ 